\title{
IMPACT OF DIFFERENT FERTILIZATION REGIMES ON THE BIOMASS PRODUCTION OF PERENNIAL GRASS MISCANTHUS $\times$ GIGANTEUS IN SLOVAKIA
}

\author{
KOTRLA, M. - PAUKOVÁ, Ž. - PRČIK, M. \\ Faculty of European Studies and Regional Development, Slovak University of Agriculture in \\ Nitra, Tr. A. Hlinku 2, 94976 Nitra, Slovakia \\ (phone: +421-37-641-5613; fax: +421-37-641-5730) \\ Corresponding author \\ e-mail: marian.kotrla@uniag.sk; phone: +421-37-641-5613 \\ (Received $2^{\text {nd }}$ Jul 2019; accepted $16^{\text {th }}$ Oct 2019)
}

\begin{abstract}
Miscanthus energy grass, being one of the renewable energy sources, has suitable soil-climatic conditions for growth in the regions of Slovakia. The lifespan of a Miscanthus plantation is 15-20 years. In the specific conditions of southwestern Slovakia, the plantation productivity was studied under the application of NPK fertilizer after one third of the plantation's lifespan. The measurement interval was 14 days throughout the growing period of the monitored years (2016-2018). Morphometric and selected ecophysiological and production parameters were analysed under three fertilization variants $(\mathrm{C}-$ control, $\mathrm{V} 1$ - variant with the application of $50 \mathrm{~g} \mathrm{NPK}$ per individual and V2 - variant with the application of $100 \mathrm{~g}$ NPK per individual). Variant V2 had the highest values of the studied parameters in all monitored years and out of all fertilization variants. The statistical significance of differences in growth indicators between the years of cultivation and total biomass production between variants and years was confirmed. Dynamics of stomatal density per $\mathrm{mm}^{2}$ were determined by microrelief method in three randomly selected clumps of Miscanthus $\times$ giganteus in control and in each variant of fertilization in 2016. There are significant differences in the density stomatal density and width between the control and variants of fertilization in 2016.
\end{abstract}

Keywords: NPK fertilizer, energy grass, growth parameters, production, stomata

\section{Introduction}

The use of biomass as a renewable energy source is rapidly increasing worldwide. Further increases in the use of these resources can be achieved through technological development, long-term planning, implementation of integration strategies and appropriate investment. Biomass as an energy source is an easily accessible that is both technologically and ecologically acceptable. The focus on biofuels is increasing due to the reduction of dependence on fossil fuels and the stimulation of rural development and agriculture.

Miscanthus $\times$ giganteus is a perennial, warm-season Asian grass with the $\mathrm{C}_{4}$ photosynthetic pathway. In the search for ideal bioenergy crops following the oil crisis of the 1970s, evaluations to determine the biomass yield potential of giant miscanthus began across Europe. Miscanthus $\times$ giganteus grows to a height of $4 \mathrm{~m}$, produces shoots with a length of up to $4 \mathrm{~m}$ and a diameter of approx. $10 \mathrm{~mm}$, and can be grown in one location for up to 15-20 years (Dubis et al., 2017).

Miscanthus plantations have several environmental benefits compared to annual crops. These plantations can use water and nutrients more efficiently, they are resistant to pests and diseases and do not require annual soil cultivation (Cadoux et al., 2012). Miscanthus $\times$ giganteus grows very rapidly and produces a high yield of aboveground biomass at relatively low input costs (Clifton-Brown et al., 2015; Roncucci et al., 2015). 
The cultivation and high yield of Miscanthus $\times$ giganteus are characterized in various climatic and environmental conditions. Higher productivity has also been identified on less productive and marginal soils (Stavridou et al., 2017). Miscanthus $\times$ giganteus has low soil fertility requirements, tolerates cultivation on light soils and has no high nitrogen requirements (Kołodziej et al., 2016).

Several authors have observed the impact of Miscanthus plantation fertilization on its production (Maughan et al., 2012; Dierking et al., 2016). Larsen et al. (2014) reported that fertilization of the Miscanthus $\times$ giganteus did not increase the yield. Other authors suggest that yields can be increased by applying annual fertilizers to older stands (Arundale et al., 2014).

To predict the production potential of energy plant species in a particular region, it is necessary to identify the basic morphometric and ecophysiological parameters and their changes due to environmental factors. The shape of organs, especially leaves, often shows the ability to adapt to environmental conditions. These include irradiation density, drought, and extreme temperatures, change anatomy and leaf morphology, skin thickness, stomata density, size, and degree of stomata openness. The stomata density is a relatively plastic feature that is potentially adaptable to environmental changes (Killi et al., 2018; Mwendia et al., 2019).

This article presents the results of the influence of various fertilization variants applied after the sixth growing period of the stand on the morphometric, selected ecophysiological and production parameters of the Miscanthus $\times$ giganteus plantation in the conditions of southwestern Slovakia.

\section{Materials and Methods}

\section{Plant materials}

Perennial grass Miscanthus $\times$ giganteus is a vital triploid hybrid (57 chromosomes) often used in the field trials. The planting material consisted of rhizomes from Hannes Stelzhammer Austria. The fresh weight of the rhizomes was different (on average $2.61 \mathrm{~g}$ ), the length of the rhizomes was on average $67.5 \mathrm{~mm}$.

\section{Model locality of the research area}

The model area of experimental research of growing fast-growing plants on agricultural soils is located in Slovakia in Nitra region in the cadastral area of Kolínany $\left(48^{\circ} 21^{\prime} 21^{\prime \prime} \mathrm{N} 18^{\circ} 12^{\prime} 25^{\prime \prime} \mathrm{E}\right)$. The area has an altitude of $80 \mathrm{~m}$ above sea level. The soil is moderate (loam), $\mathrm{pH}$ values range from 7.18 to 7.35 , humus content is 1.16 to $2.50 \%$ (Demo et al., 2013). In terms of exposure, it is a plane without manifestation of areal erosion. According to climatic conditions the research area belongs to the warm, very dry, lowland climate region. The basic climatic parameters (Table 1) were evaluated based on the measurements of the Meteorological station located near the research area. The values were compared with the long-term average values of the 50-year period of 1951-2000 in the Nitra region, according to Slovak Hydrometeorological Institute (Fig. 1). The average annual air temperature for the period 2015 to 2018 was $10.99^{\circ} \mathrm{C}$ (the deviation from the long-term average was higher by $1.13^{\circ} \mathrm{C}$ ) and the average annual precipitation was $483.67 \mathrm{~mm}$ (the deviation from the long-term annual total was lower by $63.93 \mathrm{~mm}$ ). The average length of the main growing period during the monitored years in the research area is 186 days. 
The research plot was established in 2010. The plant material was planted in a $1 \mathrm{~m} \times$ $1 \mathrm{~m}$ planting distance on an area of $100 \mathrm{~m}^{2}$. The optimum Miscanthus stand density is 10,000 plants per hectare, depending on the abiotic conditions of the habitat - temperature and water. In the research area, Miscanthus $\times$ giganteus rhizomes were planted in wet soil at the beginning of the growing period at a depth of up to $10 \mathrm{~cm}$.

Table 1. Average monthly precipitation and course of average monthly temperatures in 20152018 in the research area in Kolińany, southwestern Slovakia

\begin{tabular}{c|c|c|c|c|c|c|c|c|c|c|c|c}
\hline $\begin{array}{c}\text { 4 year } \\
\text { average } \\
\text { / month }\end{array}$ & I & II & III & IV & V & VI & VII & VIII & IX & X & XI & XII \\
\hline $\mathrm{mm}$ & 40.20 & 50.10 & 45.34 & 35.20 & 53.50 & 46.65 & 54.75 & 22.90 & 27.48 & 23.35 & 43.95 & 40.25 \\
\hline${ }^{\circ} \mathrm{C}$ & -1.02 & 1.95 & 6.05 & 11.42 & 16.27 & 20.17 & 21.77 & 21.81 & 16.39 & 10.48 & 5.55 & 1.05 \\
\hline
\end{tabular}
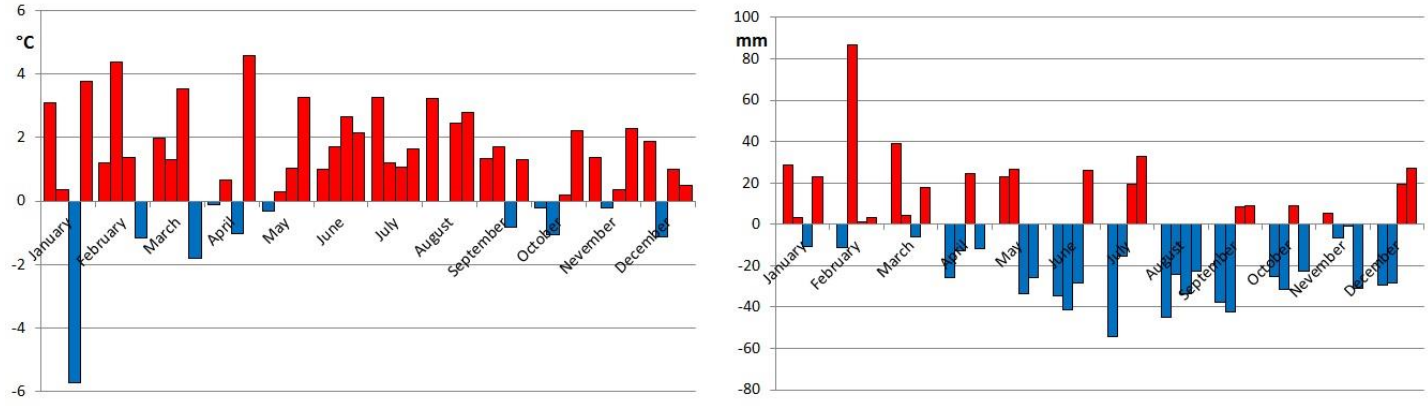

Figure 1. Average monthly deviations of temperature and average monthly deviations of total precipitation in 2015-2018 from the long-term average in research area in Koliñany

\section{Application of different fertilization regimes}

The mineral granular fertilizer N P K (15-10-10), type designation B.1, was applied before to the beginning of the growing period (beginning of April in 2016 - after the sixth growing year since the plantation was established). The fertilizer contained $15 \%$ of total nitrogen $[\mathrm{N}], 10 \%$ of total phosphorus $\left[\mathrm{P}_{2} \mathrm{O}_{5}\right]$ and $10 \%$ of water-soluble potassium $\left[\mathrm{K}_{2} \mathrm{O}\right]$. The fertilizer was applied at the centre of the tillering circle of each individual before the growth of new shoots (Fig. 2).

In the V1 variant, $50 \mathrm{~g}$ of fertilizer per individual $(500 \mathrm{~kg}$ per hectare of which $75 \mathrm{~kg}$ of nitrogen, $50 \mathrm{~kg}$ of phosphorus and $50 \mathrm{~kg}$ of potassium per ha) was applied. In the $\mathrm{V} 2$ variant, $100 \mathrm{~g}$ per individual (1000 kg per hectare of which $150 \mathrm{~kg}$ of nitrogen, $100 \mathrm{~kg}$ of phosphorus and $100 \mathrm{~kg}$ of potassium per ha) was applied and variant $\mathrm{C}$ (control) remained without fertilization. A schematic representation of the research area with variants of fertilization is shown in Fig. 3.

\section{Monitored the growth parameters and production yield}

Basic morphometric characteristics of Miscanthus $\times$ giganteus were studied for all three variants. The interval of measurement of morphometric parameters was every 14 days during the whole growing period of the monitored years (2016-2018) at 14 selected individuals. The height of the individuals was determined as the distance from the soil surface to the top of the longest shoot. The number of shoots on individual plants 
was determined by counting the shoots in the clump. The shoot thickness was measured on the selected shoot of the studied individuals. The number of leaves on the shoot and the number of leaves in the clump were monitored. Accordingly, the senescence of the leaves on the shoot was determined. In the case of energy plants, a destructive determination of the biomass weight is carried out outside the growing period. After cutting, the total weight of the selected individuals (seven clumps from each variant) was determined. The biomass sample was oven-dried at $105^{\circ} \mathrm{C}$ and the dry weight was determined. The moisture content of Miscanthus $\times$ giganteus ranges from 19 to $22 \%$. The total weight of the above-ground biomass was calculated ( $\mathrm{t} / \mathrm{ha})$.

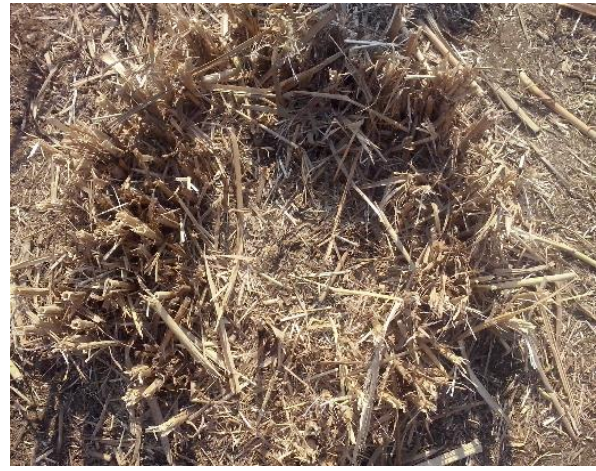

Figure 2. The tillering circle of Miscanthus $\times$ giganteus before the application of the fertilizer in the beginning of the seventh growing period

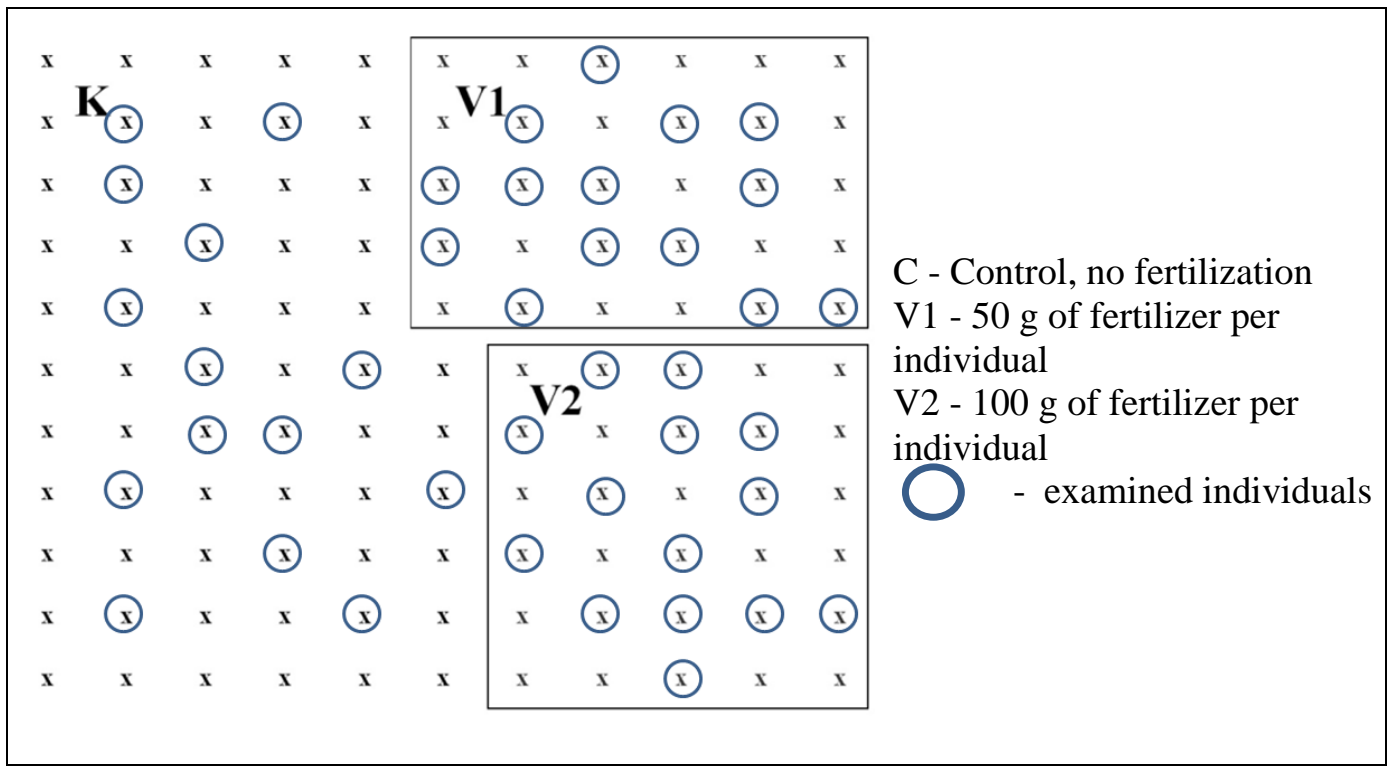

Figure 3. The schema of application of different fertilization regimes in the research area of Miscanthus $\times$ giganteus

The stomatal density per $\mathrm{mm}^{2}$ in the leaves was determined non-destructively in three selected clumps in each fertilization variant in 2016. The indicated number of the stomata refers to one treatment. The analysis was performed on the designated stem on the senescence leaf located in the middle of the stand (approximately fifth leaf from the 
bottom) exposed to western direction by a micro-relief method. Samples were collected in the middle part of the leaf outside the main vein on the adaxial (top) and abaxial (bottom) skin surface in August 2016. The evaluation of preparations was carried out by optical microscope Axiostar plus, Carl Zeiss lens, CP-Achromat $40 \times /$ 0.65, $10 \times$ eyepiece PI / 18, Canon Utilities software Zoom Browser EX 4.6 and hardware Acer Travel Mate 4600, Canon Power Shot A 95. In total, 144 microscopic view-fields were considered in the counting. Stomata length and width were measured on 162 randomly selected stomata.

Statistical analysis of morphometric and production data was performed using STATISTICA 12 by StatSoft. Inc. ANOVA analysis was used to analyse the statistical significance of morphometric and production indicators between years and variants. The result is statistically significant if $p<0.05$ or statistically highly significant if $p<0.001$. Statistical significance of stomatal differences was evaluated by LSD-test.

\section{Results and Discussion}

The basic prerequisite for the efficiency of growing plants for energy purposes is the ability of the species to adapt to the region's climate. Without fertilization, Miscanthus $\times$ giganteus has produced an economically efficient above-ground biomass every year since planting in 2010 (Kotrla et al., 2017; Kotrla and Prčík, 2018). In 2016, fertilization was applied to identify the need for fertilization in relation to the growth and production of biomass of the energy grass.

\section{Morphometric analysis of Miscanthus $\times$ giganteus}

Production of usable biomass for energy use is realized through the formation of above-ground organs. The growth of above-ground organs is limited by the length of the growing period. In 2016 and 2017, the growing period was 176 days and in 2018 it was 219 days. In 2018 , average daily temperatures above $10^{\circ} \mathrm{C}$ began at the beginning of April and ended at the beginning of November compared to previous years.

Fig. 4 represents the course of growth of selected parameters between 2016 and 2018 in the different fertilization variants. The V2 variant had the highest values of the growth parameters in all studied years and fertilization variants. The comparison of the monitored growth parameter values at the end of the growing period 2016 to 2018 is shown in Table 2.

The number of shoots in the clump increases at the beginning of the growing season culminates in the second half of June and subsequently decreases (Fig. 4a). The shoots continue with intense growth and higher production of green leaves in June, resulting in the drying of shoots in the middle of the clump. The reason for reducing the number of shoots is the competitive struggle of shoots for space, especially light.

In each year, V2 variant has reached the highest height of the clump. When comparing the variants, V1 variant was on average lower by $3.5 \%$ and the $\mathrm{C}$ variant was on average lower by $6.5 \%$ than $\mathrm{V} 2$ variant at the end of the growing period. Based on the analysis of the shoot thickness, it can be stated that the shoots in the $\mathrm{V} 1$ and $\mathrm{C}$ variants were on average thinner by $1.8 \%$ and $2.7 \%$, respectively compared to the variant V2. The number of leaves is closely related to the height of the shoots. The dynamics of the number of green leaves on the shoots is shown in Fig. $4 d$ and e. Senescence of the leaves (yellowing and drying) begins in the second half of June and continues until the end of the growing period. The ratio of green and dry leaves on the shoot intensely changes in early October 
in favour of dry leaves. This trend continues until the end of the growing period when the photosynthetic activity of the leaves ends. The average number of leaves in the variant V2 was $3.3 \%$ higher than in the variant V1 and $15.2 \%$ higher compared to the variant $\mathrm{C}$. Drazić et al. (2017) examined the impact of fertilization on Miscanthus stand in Serbia. They confirmed the increase in morphometric characteristics of fertilized variants. Pogrzeba et al. (2017) also monitored plant growth parameters for fertilized and nonfertilized varieties in Poland. They found no significant differences between these variants.
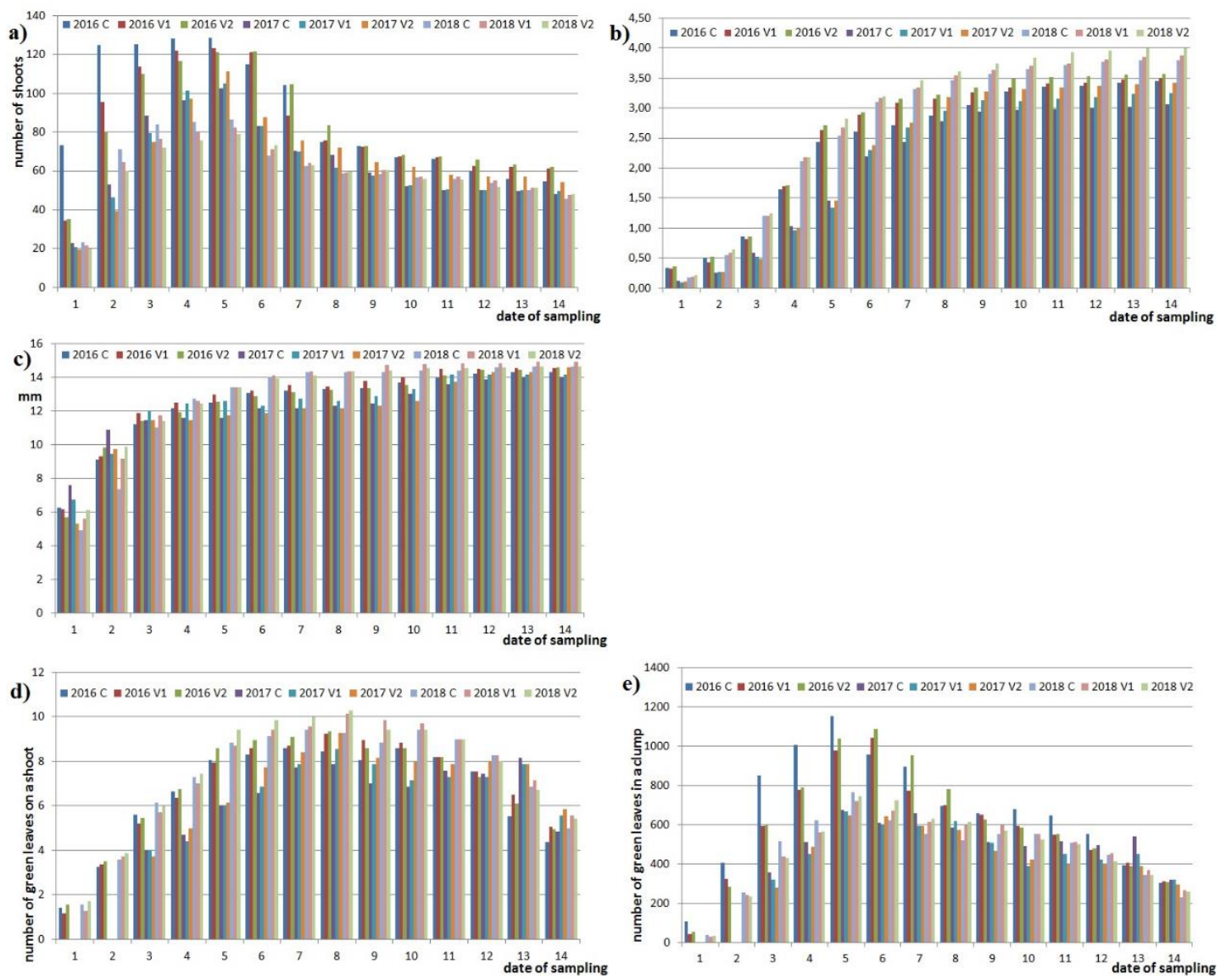

Figure 4. Morphometric analysis of Miscanthus $\times$ giganteus stand in monitored years and fertilization variants (a) number of shoots in a clump, b) height of shoots in a clump, c) shoot diameter, d) number of green leaves on a shoot, e) number of green leaves in a clump]

The analysis confirmed the statistical significance of the growth parameters between the variants and years. The statistical significance of the growth rate values over the growing period is statistically highly significant only between the monitored years. The reason is the different climatic conditions during the growing period of these years. In each year, the values of the growth parameter between variants C, V1 and V2 are statistically non-significant (Table 3).

\section{Production potential of Miscanthus $\times$ giganteus}

Annual production of the shoots of Miscanthus $\times$ giganteus represents an amount of biomass usable as an alternative energy source. Fig. 5 shows the variability of the biomass 
samples collected at the end of February in the following year. Differences in the aboveground biomass weight between years and variants are statistically highly significant (Fig. O). The statistical significance between years $(\mathrm{p}=0.00029)$ and also between variants $(p=0.00019)$ was confirmed at the significance level of 0.001 .

Table 2. Comparison of growth parameter values at the end of the growing period 2016 to 2018 in different fertilization variants

\begin{tabular}{c|c|c|c|c|c|c|c|c|c}
\hline Year & \multicolumn{3}{|c|}{$\mathbf{2 0 1 6}$} & \multicolumn{3}{c|}{$\mathbf{2 0 1 7}$} & \multicolumn{3}{c}{$\mathbf{2 0 1 8}$} \\
\hline Variant / growth parameter & C & V1 & V2 & C & V1 & V2 & C & V1 & V2 \\
\hline number of shoots in a clump & 54.64 & 61.29 & 62.29 & 48.05 & 49.71 & 54.29 & 45.71 & 47.57 & 48.14 \\
height of shoots [m] & 3.44 & 3.50 & 3.57 & 3.06 & 3.25 & 3.42 & 3.80 & 3.87 & 4.00 \\
shoot diameter in a clump [mm] & 14.31 & 14.54 & 14.60 & 14.00 & 14.14 & 14.57 & 14.62 & 14.63 & 14.93 \\
number of green leaves on a shoot & 4.37 & 4.94 & 5.07 & 4.86 & 5.57 & 5.86 & 5.00 & 5.43 & 5.57 \\
number of green leaves in a clump & 238.67 & 302.75 & 315.79 & 233.39 & 276.98 & 317.96 & 228.57 & 258.24 & 268.22 \\
\hline
\end{tabular}

Table 3. Statistical significance of selected growth and production parameters of Miscanthus $\times$ giganteus organs in the studied years and fertilization variants

\begin{tabular}{c|c|c|c|c}
\hline \multirow{2}{*}{ Parameter } & \multicolumn{2}{|c|}{ Years } & \multicolumn{2}{c}{ Variants } \\
\cline { 2 - 5 } & p-value & S & p-value & $\mathrm{n}$ \\
\hline number of shoots & 0.00001 & $* * *$ & 0.85937 & $\mathrm{n}$ \\
height of shoots & 0.04148 & $*$ & 0.79439 & $\mathrm{n}$ \\
$\begin{array}{c}\text { shoot diameter } \\
\text { number of green leaves on }\end{array}$ & 0.03071 & $*$ & 0.09866 & $\mathrm{n}$ \\
$\begin{array}{c}\text { a shoot } \\
\text { number of green leaves in }\end{array}$ & 0.01412 & $*$ & 0.80012 & $\mathrm{n}$ \\
$\begin{array}{c}\text { a clump } \\
\text { weight of an individual }\end{array}$ & 0.00032 & $* * *$ & 0.73284 & $* * *$ \\
\hline
\end{tabular}

$\mathrm{S}$ - Level of significance is defined as: $\mathrm{n}$ : non-significant impact, *: significant impact in $\mathrm{P} \leq 0.05$, **: $\mathrm{P}$ $\leq 0.01$ and $* * *: \mathrm{P} \leq 0.001$

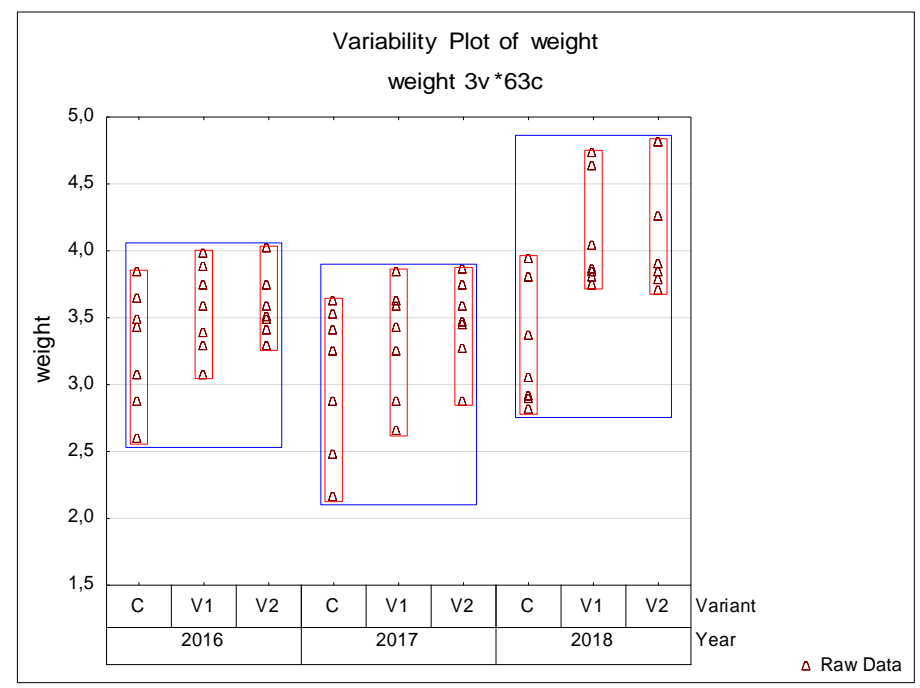

Figure 5. Variability of biomass samples of the above-ground organs of Miscanthus $\times$ giganteus in the studied years and variants of fertilization 
Biomass production increased every year in the research area. Since 2015, slight fluctuations in total biomass production have been monitored (Table 4). In 2015, the summer was characterized by low precipitation compared to the long-term average. After the application of fertilizer at the beginning of the 2016 growing period, an increase in biomass was observed in fertilized variants compared to the control variant. The variant without fertilization also produced $8.5 \%$ more biomass than in the previous year (2015). The difference between the yield in 2015 and biomass yield without fertilization in 2016 is statistically significant $(\mathrm{p}=0.01560)$. When comparing the produced biomass between the non-fertilized and fertilized variants, it is possible to state the average increase in fertilized variants by $7.6 \%$ in 2016, 10.1\% in 2017 and $13.5 \%$ in 2018 .
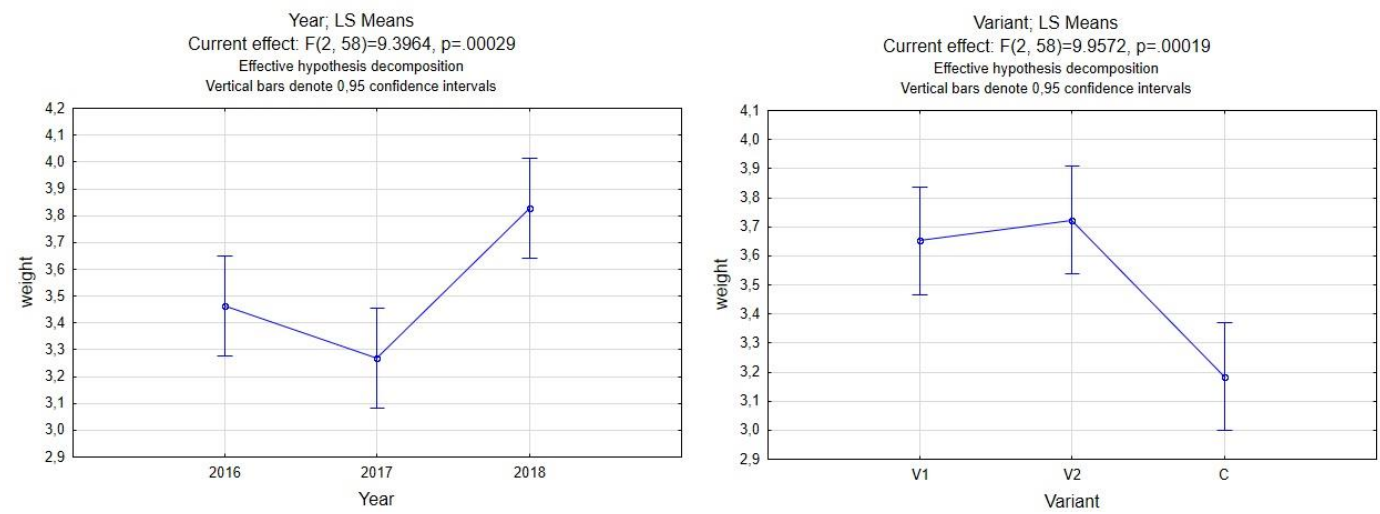

Figure 6. Statistical analysis of the above-ground biomass weights in the studied years and fertilization variants

Table 4. The production of biomass of Miscanthus $\times$ giganteus in the fertilization variants since 2016 and compared with 2015 in the research plot in Kolinany

\begin{tabular}{c|c|c|c|c}
\hline Year /Variant & $\mathbf{2 0 1 5}$ & $\mathbf{2 0 1 6}$ & $\mathbf{2 0 1 7}$ & $\mathbf{2 0 1 8}$ \\
\hline Variant C (without fertilization) & 30.1 & 32.69 & 30.39 & 32.97 \\
Variant V1 & & 35.03 & 33.13 & 37.17 \\
Variant V2 & & 35.74 & 34.51 & 39.1 \\
\hline
\end{tabular}

Lower levels of the biomass produced in 2017 are the result of the climatic situation, especially low temperatures at the beginning of the growing period and spring frosts in late April and early May. The night frost, as a negative phenomenon in 2017, was recorded in the first decade of May (the minimum temperature of $-0.196^{\circ} \mathrm{C}$ was on the 10th of May). These spring frosts negatively affected the growth of the shoots in 2017.

Iqbal et al. (2015) analyzed the stands of energy grasses in a period of ten years. They confirmed that the application of fertilizers did not significantly increase the yield of Miscanthus. On the contrary, Dubis et al. (2017) monitored the effect of different fertilization methods on Miscanthus productivity. The application of NPK fertilizer increased the biomass yield by $7.7 \%$ compared to the non-fertilized variant. Arundale et al. (2014) applied fertilization to older energy grass stand in Illinois, USA. They confirmed an increase in the yield of the fertilized variant compared to the non-fertilized variant by $25 \%$. In the Midwest of the USA, Lee et al. (2017) confirmed a statistically highly significant increase in Miscanthus yield compared to the non-fertilized variant, but they did not confirm the differences in the total production between higher and lower 
fertilizer doses. Several authors have done fertilization experiments in the first years after planting. However, in the conditions of southwestern Slovakia, it was not necessary to apply fertilizer in the first years, as the energy grass had been reaching an economically profitable yield. The Miscanthus stand had shown the culmination of the yield after the sixth year since the establishment, so the fertilization was applied at the beginning of the seventh growing period (which is about a third of the plant's lifespan). Maksimović et al. (2018) observed the effect of fertilization in the first years of the establishment of the Miscanthus plantation in Serbia, but they did not find significant differences in biomass production. They confirmed that the profitability of the plantation is affected also by climatic conditions in individual years.

\section{Analysis of the stomata of Miscanthus $\times$ giganteus leaves}

Photosynthetic performance of Miscanthus leaves and their production ability is also influenced by the anatomical structure of assimilation organs. The density and the size of stomata are critical. The stomata play an irreplaceable role in venting the gases between the plant and the atmosphere and they are the place of regulated water discharge in the transpiration process. Their development and movements are indicated by environmental factors.

The number of stomata in leaves was statistically highly significantly affected by adaxial and abaxial leaf surface of the epidermis of Miscanthus $\times$ giganteus (LSD0,05 test \pm 12.87$)$. The ratio of stomata was $32: 68$ on the adaxial and abaxial leaf surface, respectively. The number of stomata per $\mathrm{mm}^{2}$ of area varied from $97.8 \pm 15.0$ to $223.6 \pm$ 28.2. Between control and variants of fertilization are significant differences in the density of stomata (LSD 0,05 test \pm 7.19 on the adaxial skin, 11.24 on the abaxial skin) (Fig. 7a). On the contrary, Weng and Hsu (2001) found that the $\mathrm{N}$ treatment could increase the stomatal frequency on the adaxial surface in most tested Miscanthus clones in Taiwan, however, no significant effect was observed on that of the abaxial surface.

a)

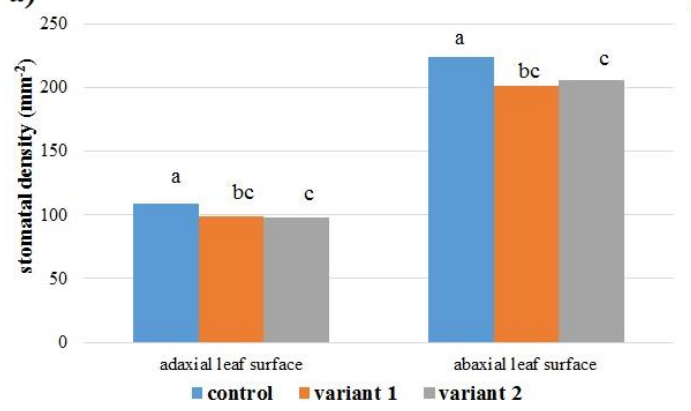

b)

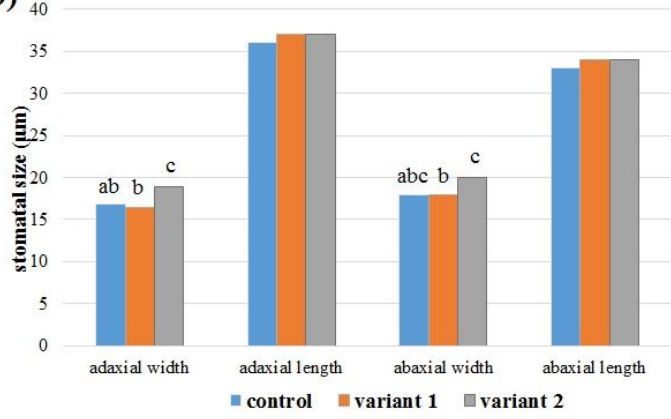

Figure 7. a) The number of stomata per $\mathrm{mm}^{2}$ of the adaxial and abaxial surface depending on the variants of fertilization. $b$ ) Statistical evaluation of significant differences in the size of stomata $(\mu \mathrm{m})$ depending on fertilization. Values with different letters $(a, b, c)$ in columns indicate statistically significant difference according to LSD test $(P<0.05)$

The stomatal length ranged from $33.5 \pm 2.1 \mu \mathrm{m}$ to $37.4 \pm 4.0 \mu \mathrm{m}$, and stomatal width from $16.6 \pm 1.8 \mu \mathrm{m}$ to $19.8 \pm 2.6 \mu \mathrm{m}$ (Fig. 7 b). Rayburn et al. (2009) also compared the size of stomata of two Miscanthus genotypes in the USA and confirmed genotypic conditionality of the monitored indicator expressed by the average length of stomata of 
Miscanthus $\times$ giganteus $24.4 \mu \mathrm{m}$. Moon et al. (2018) recorded the average length of stomata of Miscanthus $\times$ giganteus ranging from 21 to $28.5 \mu \mathrm{m}$. In our observations, the average length of stomata of Miscanthus $\times$ giganteus was higher $35.6 \mu \mathrm{m}$.

Differences in stomatal width of leaves between control and variants of fertilization on the adaxial surface and between variants $\mathrm{V}$ of fertilization on the abaxial surface and V2 were highly significant (LSD 0,05 test \pm 1.07 on the adaxial skin, 1.49 on the abaxial skin), while no significant differences were observed in stomatal lengths (Fig. 7b).

\section{Conclusion}

The plantation of Miscanthus $\times$ giganteus grown in soil-climatic conditions in southwestern Slovakia produced an effective yield (more than $30 \mathrm{t} / \mathrm{ha}$ ) of the above-ground biomass every year. At the beginning of the seventh growing period, NPK mineral granular fertilizer was applied in order to determine the effect of fertilization on crop yield after the first third of the plantation lifespan. The Miscanthus stand was divided into three variants, two with different fertilizer doses and one without fertilization. In the growing periods of 2016-2018, morphometric, selected ecophysiological and production parameters were measured. The morphometric analysis confirmed higher growth performance of the fertilized variants. The statistical analysis of the growth parameters is highly statistically significant only between the monitored years. In each year, the values of the growth parameters between the variants $\mathrm{C}, \mathrm{V} 1$ and V2 were statistically nonsignificant. Differences between variants and years were statistically highly significant in total biomass production. Statistical significance between the years $(p=0.00029)$ and also between the variants $(\mathrm{p}=0.00019)$ in the biomass production was confirmed at the significance level of 0.001 .

As a factor affecting the production ability of the Miscanthus plantation, the density and size stomata of the Miscanthus leaves were analysed. Significant differences in the density of stomata (LSD 0,05 test $\pm 7.19,11.24$ ) and stomatal width (LSD 0,05 test \pm $1.07,1.49)$ were found between the control and variants of fertilization.

Miscanthus cultivated in southwestern Slovakia produced economically efficient yield despite fertilization. The difference in fertilized and non-fertilized variations ranges from 7.6 to $13.5 \%$. The positive effect of fertilization on above-ground biomass production has been demonstrated. A possible negative phenomenon for the Miscanthus plantations production is the climatic conditions in each year of cultivation. However, fertilization at certain stages of the energy grass lifespan can maintain plantation production performance even in the later years of cultivation. The aim of further studies will be to find out the period of culmination and decrease in biomass production of Miscanthus $\times$ giganteus in the conditions of southwestern Slovakia and subsequently to apply another dose of fertilization.

Acknowledgements. This work was supported by the Grant Agency FESRD as projects no. 3/2017 and no. 2/2017, and by the AgroBioTech ITMS 26220220180. 


\section{REFERENCES}

[1] Arundale, R. A., Dohleman, F. G., Voigt, T. B., Long, S. P. (2014): Nitrogen fertilization does significantly increase yields of stands of Miscanthus $\times$ giganteus and Panicum virgatum in multiyear trials in Illinois. - Bioenergy Res. 7: 408-416.

[2] Cadoux, S., Riche, A. B., Yates, N. E., Machet, J. M. (2012): Nutrient requirements of Miscanthus $\times$ giganteus: conclusions from a review of published studies. - Biomass and Bioenergy 38: 14-22.

[3] Clifton-Brown, J., Schwarz, K. U., Hastings, A. (2015): History of the development of Miscanthus as a bioenergy crop: from small beginnings to potential realisation. - Biology and Environment: Proceedings of the Royal Irish Academy 115(1): 45-57.

[4] Demo, M., Bako, A., Húska, D., Hauptvogl, M. (2013): Biomass production potential of different willow varieties (Salix spp.) grown in soil-climatic conditions of South-Western Slovakia. - Wood research 58(4): 651-662.

[5] Dierking, R. M., Allen, D. J., Brouder, S. M., Volenec, J. J. (2016): Yield, biomass composition, and $\mathrm{N}$ use efficiency during establishment of four Miscanthus $\times$ giganteus genotypes as influenced by $\mathrm{N}$ management. - Biomass and bioenergy 91: 98-107.

[6] Drazić, G., Milovanović, J., Ikanović, J., Petrić, I. (2017): Influence of fertilization on Miscanthus $\times$ giganteus (Greef et Deu) yield and biomass traits in three experiments in Serbia. - Plant, Soil and Environment 63(4): 189-193.

[7] Dubis, B., Bułkowska, K., Lewandowska, M., Szempliński, W., Jankowski, K. J., Idźkowski, J., Kordala, N., Szymańska, K. (2017): Effect of different nitrogen fertilizer treatments on the conversion of Miscanthus $\times$ giganteus to ethanol. - Bioresource technology 243: 731-737.

[8] Iqbal, Y., Gauder, M., Claupein, W., Graeff-Hönninger, S., Lewandowski, I. (2015): Yield and quality development comparison between miscanthus and switchgrass over a period of 10 years. - Energy 89: 268-276.

[9] Killi, D., Bussotti, F., Gottardini, E., Pollastrini, M., Mori, J., Tani, C., Papini, A., Ferrini, F., Fini, A., Richardson, A. D., Ashton, P. M. S., Berlyn, G. P., McGrody, M. E., Cameron, I. R. (2018): Photosynthetic and morphological responses of oak species to temperature and $\left[\mathrm{CO}_{2}\right]$ increased to levels predicted for 2050. - Urban forestry \& urban greening 31: 26-37.

[10] Kołodziej, B., Antonkiewicz, J., Sugier, D. (2016): Miscanthus $\times$ giganteus as a biomass feedstock grown on municipal sewage sludge. - Industrial Crops and Products 81: 72-82.

[11] Kotrla, M., Mandalová, K., Prč́́k, M. (2017): Regional disparities in Slovakia and the Czech Republic in the context of sustainable growing of energy plants. - European Journal of Sustainable Development 6(2): 165-180.

[12] Kotrla, M., Prčík, M. (2018): Assessment of climatic parameters during the vegetation period in terms of efficiency of growing of energy plants in Slovakia regions. - Scientific papers series management, economic engineering in agriculture and rural development 18(1): 203-209.

[13] Larsen, S. U., Jørgensen, U., Kjeldsen, J. B., Lærke, P. E. (2014): Long-term Miscanthus yields influenced by location, genotype, row distance, fertilization and harvest season. BioEnergy Research 7(2): 620-635.

[14] Lee, M. S., Wycislo, A., Guo, J., Lee, D., Voigt, T. (2017): Nitrogen fertilization effects on biomass production and yield components of Miscanthus $\times$ giganteus. - Frontiers in plant science 8: 544.

[15] Maksimović, J., Dželetović, Ž., Dinić, Z., Stanojković-Sebić, A., Cvetković, O., Pivić, R. (2018): Assessment of the main agro-ecological parameters effects on the cultivation of Miscanthus $\times$ giganteus grown on marginal soils in the Republic of Serbia. - Agriculturae Conspectus Scientificus 83(1): 113-117.

[16] Maughan, M., Bollero, G., Lee, D. K., Darmody, R., Bons, S., Cortese, L., Murphy, J., Gaussoin, R., Sousek, M., Williams, D., Williams, L., Miguez, F., Voigt, T. (2012): 
Miscanthus $\times$ giganteus productivity: the effects of management in different environments. - GCB Bioenergy 4: 253-265.

[17] Moon, Y. H., Lee, J. E., Yu, G. D., Song, Y. S., Lee, Y. H., Kim, K. S., Lee, K. B., Cha, Y. L. (2018): Ploidy level and reproductive organ abnormality in interspecific hybrids between tetraploid Miscanthus sacchariflorus and diploid M. sinensis bred from a single cross. - Industrial Crops and Products 116: 182-190.

[18] Mwendia, S., Yunusa, I., Sindel, B., Whalley, R., Bruhl, J. (2019): Osmotic adjustment, stomata morphology and function show contrasting responses to water stress in mesic and hydric grasses under elevated $\mathrm{CO}_{2}$ concentration. - Photosynthetica 51(1): 121-131.

[19] Pogrzeba, M., Rusinowski, S., Sitko, K., Krzyżak, J., Skalska, A., Małkowski, E., Ciszek, D., Werle, S., McCalmont, J. P., Mos, M., Kalaji, H. M. (2017): Relationships between soil parameters and physiological status of Miscanthus $\times$ giganteus cultivated on soil contaminated with trace elements under NPK fertilisation vs. microbial inoculation. Environmental Pollution 225: 163-174.

[20] Rayburn, A. L., Crawford, J., Rayburn, C. M., Juvik, J. A. (2009): Genome size of three Miscanthus species. - Plant Molecular Biology Reporter 27(2): 184-188.

[21] Roncucci, N., Nassi O Di Nasso, N., Tozzini, C., Bonari, E., Ragaglini, G. (2015): Miscanthus $\times$ giganteus nutrient concentrations and uptakes in autumn and winter harvests as influenced by soil texture, irrigation and nitrogen fertilization in the Mediterranean. Gcb Bioenergy 7(5): 1009-1018.

[22] Stavridou, E., Hastings, A., Webster, R. J., Robson, P. R. (2017): The impact of soil salinity on the yield, composition and physiology of the bioenergy grass Miscanthus $\times$ giganteus. - GCB Bioenergy 9(1): 92-104.

[23] Weng, J. H., Hsu, F. H. (2001): Gas exchange and epidermal characteristics of Miscanthus populations in Taiwan varying with habitats and nitrogen application. - Photosynthetica 39(1): 35-41. 